\title{
Energy - Efficient Reconstruction of Public Lighting in Pravets Municipality from Bulgaria
}

\author{
Veselka Kamburova ${ }^{1} \uparrow$, Violeta Rasheva, ${ }^{2, *}$ and Michail Velikanov ${ }^{3}$ \\ ${ }^{1}$ Department of Heat, Hydraulics and Environmental Engineering, University of Ruse, Bulgaria \\ ${ }^{2}$ Department of Industrial Thermal Engineering, University of Food Technologies, Bulgaria \\ ${ }^{3}$ Encon Services International, USA
}

\begin{abstract}
Improving energy efficiency and reducing greenhouse gases is a central issue of the Europe 2020 strategy. Today enormous electric energy is consumed by the street lighting. Much of it could be saved through suitable energy-conservation measures (ECMs). The energy audit of the street lighting system in the Pravets municipality was carried out in compliance with the legislation in force in the EU and Bulgaria. Data about the present state of street lighting and electricity consumption for a period of 3 years were gathered and analysed. The baseline electricity consumption was defined. Classification of streets was done and the light class of the different categories streets was determined. The potential for energy savings was identified and a package of ECMs was developed. The annual electricity savings are $680 \mathrm{MWh}$ (or $57,441 € / \mathrm{y}$ ) and the annual $\mathrm{CO}_{2}$ emissions savings are 557,640 t. The investment for implementation of the envisaged ECMs is $414,840 €$. The expected electricity savings compared to the baseline are $75 \%$.
\end{abstract}

\section{Introduction}

Global energy policy aims at limiting climate change, energy security and competitiveness. The issue of energy consumption in buildings, industry and transport stands in the heart of the EU policy on energy efficiency. A number of studies have been carried out in the EU Member States to increase energy efficiency, environmental protection and the use of renewable energy sources in buildings and industrial plants [1-5]. Some authors have explored the possibilities of saving energy from lighting in different types of buildings [6-8]. But street lighting is also a great energy consumer. Scientific and technical literature does not sufficiently monitor the possibilities of electrical energy savings in street lighting. Today as electrical savings in street lighting as well as $\mathrm{CO}_{2}$ emission reduction are very important. So there is a need for a detailed analysis of the savings in the existing street lighting systems and quality planning for new ones. Savings in the field of street lighting

\footnotetext{
† Deceased on 19.05.2019.

* Corresponding author: v rasheva@abv.bg
} 
could be better invested in other budget items in municipalities [9]. There are some attempts, in which the energy wastes of the street lights are reduced. A sensor light, which is controlled by the brightness sensor and the motion sensor, is sometimes used [10]. In recent years, Bulgaria has also been working to improve the state of street lighting systems and to reduce their electricity consumption. In this connection Bulgaria has harmonized European standard for street lighting [11] and in 2016 has published an Ordinance [12] according to which systems for outdoor artificial lighting located in settlements with over 20000 inhabitants are subject to obligatory energy audits.

One of the basic requirements of European standard for street lighting is that the average brightness of the roadway does not fall below a specified operating brightness, because the task of outdoor lighting systems (street, park, hiking, advertising, architectural, decorative lighting, etc.) is to ensure the safe movement of motor vehicles and pedestrians. Street lighting improves visibility on the road and is a prerequisite for reducing fatal crashes. Also good street lighting leads to improved security of inhabitants and to decline in criminal activities. Thanks to it, a unique night view of towns and villages is created.

According to [13], municipalities are the owners of the street lighting systems. They invest in its reconstruction, build new sections, and pay the cost for electricity consumption. Costs for street lighting represent about $3 \%$ of the total costs of the municipalities.

The aim of this study is to evaluate the state of the street lighting systems in the municipality of Pravets and to identify the potential for reducing electricity consumption through appropriate ECMs, while at the same time provide the necessary normative parameters for illumination of the streets. This in turn would reduce the cost of municipal electricity consumption and $\mathrm{CO}_{2}$ emissions into the atmosphere as well as would increase road safety.

\section{Methodology}

Pravets Municipality is situated in the western part of Bulgaria in the Sofia region. In 2017, the municipality has a territory of $324 \mathrm{~km}^{2}$ and population of 7,801 inhabitants. The town of Pravets is an administrative centre of municipality and has a territory of $46 \mathrm{~km}^{2}$ and population of 4,407 inhabitants. The municipality has 10 more villages besides the town of Pravets.

The energy audit of the existing street lighting system in municipality of Pravets covers the street lighting of the town of Pravets and the rest villages in the municipality and was carried out in 2017. The investigation involves the following steps and activities:

- Gathering basic information about the municipality, electricity consumption, the number, type and power of the street and park lighting, the number and condition of the transformer substations, the state of the street lighting supply network and the available electricity meters, the geometric parameters of the streets and the location of the street lighting poles;

- Assessment of the current state of street lighting system;

- Analysis of electricity bills, operating and maintenance (O\&M) costs and operating time of street lighting system for a period of 3 years;

- Determination of baseline energy consumption by street lighting;

- Development of phototechnical classification of the street network according to [11] and selection of normative indicators;

- Determining the potential for electricity savings;

- Development of appropriate ECMs;

- Assessment of required investment costs;

- Assessment of the savings of electricity and the O\&M cost after implementation of the ECMs;

- Techno-economic and ecological assessments of the proposed ECMs.

Assessments were performed on the basis of preliminary studies, analytical calculations and measurements were carried out using specialized measuring devices according to [14]. 
The next normative documents [11-12, 15-19] were used to assess the state of the street lighting in the municipality and to determine the ECMs.

\section{Technical condition of street lighting in municipality of Pravets}

The main supplier of electricity for the municipality is "CEZ Bulgaria" EAD, as deliveries are made through transformers $20 / 0.4 \mathrm{kV}$. In the street lighting panels there is no protection against atmospheric overvoltage and increased voltage due to zeroing. The existing street lighting system of the town of Pravets and settlements in the municipality is morally and physically obsolete, depreciated and energy-intensive and requires investment for reconstruction and replacement. The distribution network for street lighting is built consistently with the expansion of urban areas and in certain sections, updated according to the incidents on them and depending on the funds available for investment. The power supply is single phase, the network is airy, located on insulators and steel poles, and is mainly made with non-insulated conductor and partially with AL/R twisted conductors. Power supply via underground cables is applied only to a small number of lighting poles and park lighting within the town of Pravets.

The existing lighting is realizeded with the following technologies of lamps: mercury vapor (MV) with power of $125 \mathrm{~W}$; high pressure sodium (HPS) with power of $100 \mathrm{~W}, 70 \mathrm{~W}$ and $50 \mathrm{~W}$; compact fluorescent lamps (CFL) with power of $55 \mathrm{~W}, 36 \mathrm{~W}$ and $25 \mathrm{~W}$; decorative compact fluorescent lamps with power of $125 \mathrm{~W}$ and lamps type "ball" with power of $85 \mathrm{~W}$.

The long-term operation of most lighting fixtures has led to their amortization pollution, corrosion of the luminaires and their reflectors. In luminaires with mercury vapor lamps, most of the light (about 60\%) is lost as it is emitted in the upper hemisphere, and causes considerable light pollution. These are the main reasons most of the luminaires to function with impaired working parameters of light output and thus with low efficiency. In some areas regulated norms of the lighting parameters are not met. In general, the existing lighting system uses obsolete technologies and is in poor technical and operational condition. The categorization, the photometric requirements for the different types of zones and the design of the street lighting network are in line with the old Bulgarian Standard [20], which is now replaced by the new European standard [11]. Under the requirements of the new standard, streets and parks are classified into separate categories depending on the required lighting of the area.

Most switchboards of street lighting are located in transformer substations. In accordance with the [13], these substations are owned by the electricity supplier. Distribution boards for street lighting must be removed outside of the supplier's property.

The control of street lighting is done mainly by automatic relays produced in Bulgaria. The control system operates on a predetermined time schedule, which is a relatively simple approach, but the main disadvantage is the lack of a centralized control system. The starting and switching devices for street lighting are located in the street lighting switchboards. Switching and protection equipment for street lighting are installed in low voltage panel inside a power substation. Most of the street lighting switchboards are not in good technical condition and need major overhaul, and some of them from replacement.

From the analysis of the current state of street lighting in the municipality of Pravets, it was found that the number of unlit streets is high and in certain sections of some illuminated streets there is a large irregularity of illumination. In this state, street lighting does not meet the requirements of the street lighting standard [11]. As a result of the street lighting survey the number, power and types of existing street lighting in Pravets and in the rest villages of the municipality respectively are presented in Tables 1 and 2 . 
Table 1. The number, power and types of existing street lighting in Pravets

\begin{tabular}{|c|c|c|c|c|c|}
\hline № & Lighting type & $\begin{array}{c}\text { Number of } \\
\text { lighting }\end{array}$ & $\begin{array}{c}\text { \% } \\
\text { of all }\end{array}$ & $\begin{array}{c}\text { Lamp power } \\
\text { +SRD, W }\end{array}$ & $\begin{array}{c}\text { Total installed } \\
\text { power, } \mathbf{~ W}\end{array}$ \\
\hline 1 & HPS 50 W & 90 & 5.38 & 64 & 5.760 \\
\hline 2 & HPS 70 W & 510 & 30.50 & 87 & 44.370 \\
\hline 3 & HPS 100 W & 69 & 4.13 & 120 & 8.280 \\
\hline 4 & CFL 25 W & 426 & 25.48 & 25 & 10.650 \\
\hline 5 & CFL 36 W & 54 & 3.23 & 45 & 2.430 \\
\hline 6 & CFL 55 W & 116 & 6.94 & 65 & 7.540 \\
\hline 7 & HPS 150 W & 132 & 7.89 & 175 & 23.100 \\
\hline 8 & type "ball" $85 \mathrm{~W}$ & 158 & 9.45 & 85 & 13.430 \\
\hline 9 & MV 125 W & 75 & 4.49 & 140 & 10.500 \\
\hline 10 & LED 40 W & 2 & 0.12 & 40 & 0.080 \\
\hline 11 & LED 60 W & 40 & 2.39 & 60 & 2.400 \\
\hline & Total & $\mathbf{1 6 7 2}$ & $\mathbf{1 0 0}$ & - & $\mathbf{P}_{\mathbf{i}}=\mathbf{1 2 8 . 5 4 0 ~ k W}$ \\
\hline
\end{tabular}

Table 2. The number, power and types of existing street lighting in the villages of the municipality

\begin{tabular}{|c|c|c|c|c|c|}
\hline № & Lighting type & $\begin{array}{c}\text { Number of } \\
\text { lighting }\end{array}$ & \% of all & $\begin{array}{c}\text { Lamp power } \\
\text { + SRD, W }\end{array}$ & $\begin{array}{c}\text { Total installed } \\
\text { power, } \mathbf{k W}\end{array}$ \\
\hline 1 & HPS 50 W & 447 & 46.18 & 64 & 28.608 \\
\hline 2 & CFL 15 W & 18 & 1.86 & 15 & 0.270 \\
\hline 3 & CFL 25 W & 5 & 0.52 & 25 & 0.125 \\
\hline 4 & CFL 36 W & 498 & 51.44 & 45 & 22.410 \\
\hline & Total & $\mathbf{9 6 8}$ & $\mathbf{1 0 0}$ & - & $\mathbf{P i}=\mathbf{5 1 . 4 1 3} \mathbf{~ k W}$ \\
\hline
\end{tabular}

\section{Electricity consumption in the municipality}

Data from the bills for electricity consumption in the municipality of Pravets for 3 years before the energy audit are presented in Table 3. The figures for the analyzed period show that the total electricity consumption for street lighting on the territory of the municipality is increasing. Electricity consumption in 2015 reaches $535,844 \mathrm{kWh}$ per year, which is $18.8 \%$ more than in 2014 . In 2016, electricity consumption continues to increase to 629,453 $\mathrm{kWh}$ per year or consumption increase is $39.6 \%$ compared to 2014 . The increase in energy consumption concerns the town of Pravets and is mainly due to the expansion of the lighting system. Figures show that there is a drop in the energy consumption of some villages during the analysis period. This could be explained by the partial repairs of street 
lighting, where some luminaires have been replaced with new, energy-efficient ones. But in most cases, the drop in consumption is due to non-glowing lamps, disconnected power supply to lamps and other incidents.

Table 3. Electricity consumption in the municipality of Pravets for 3 years

\begin{tabular}{|c|c|c|c|c|c|c|}
\hline \multirow{2}{*}{ Settlement } & \multicolumn{2}{|c|}{$\mathbf{2 0 1 4}$} & \multicolumn{2}{c|}{$\mathbf{2 0 1 5}$} & \multicolumn{2}{c|}{$\mathbf{2 0 1 6}$} \\
\cline { 2 - 7 } & $\mathrm{kWh} / \mathrm{y}$ & $\mathrm{BGN} / \mathrm{y}$ & $\mathrm{kWh} / \mathrm{y}$ & $\mathrm{BGN} / \mathrm{y}$ & $\mathrm{kWh} / \mathrm{y}$ & $\mathrm{BGN} / \mathrm{y}$ \\
\hline Town of Pravets & 254,295 & 42,088 & 382,436 & 64,841 & 509,323 & 84,292 \\
\hline Other villages & 196,565 & 32,011 & 153,408 & 26,086 & 120,130 & 19,885 \\
\hline Total & $\mathbf{4 5 0 , 8 6 0}$ & $\mathbf{7 4 , 0 9 9}$ & $\mathbf{5 3 5 , 8 4 4}$ & $\mathbf{9 0 , 9 2 7}$ & $\mathbf{6 2 9 , 4 5 3}$ & $\mathbf{1 0 4 , 1 7 7}$ \\
\hline
\end{tabular}

The current technical and operational state of the street lighting system in the municipality of Pravets is the closest to those of 2016. Based on the above fact, 2016 was chosen to be representative.

During the audit, it was found that the operating hours of street lighting in the town of Pravets are 4,150 h/year and in the rest villages of municipality $-4,100 \mathrm{~h} /$ year. The total installed power in the town of Pravets is $128.54 \mathrm{~kW}$. The annual electricity consumption for street lighting for year-round and full-night illumination at $100 \%$ working lamps is:

$$
\text { Eyear }=128.54 * 4,150=533,441 \mathrm{kWh} / \mathrm{y}
$$

The annual electricity consumption according to the invoice data is $509,323 \mathrm{kWh} / \mathrm{y}$. The difference between the calculated by equation (1) and the actual consumption gives information about the percentage of working lights in the town of Pravets. Consequently, the share of working street lighting in the town of Pravets is about $95.5 \%$ of total 1,672 number of luminaries. Applied per 1 inhabitant, the calculated specific electricity consumption is $121.04 \mathrm{kWh} /$ year and the actual specific consumption is $115.57 \mathrm{kWh} /$ year.

Similarly, the annual electricity consumption for street lighting for year-round and fullnight illumination at $100 \%$ working lamps in the rest villages of the municipality is:

$$
\text { Eyear }=51.413 * 4,100=210,793 \mathrm{kWh} / \mathrm{y}
$$

The annual electricity consumption according to the invoice data is $120,130 \mathrm{kWh} / \mathrm{y}$. The difference between the calculated by equation (2) and the actual consumption gives information about the percentage of working lights. Consequently, the share of working street lighting in the villages of the municipality is about $57 \%$ of total 968 number of luminaries. Applied per 1 inhabitant, the calculated specific electricity consumption is $62.1 \mathrm{kWh} /$ year and the actual specific electricity consumption is $35.39 \mathrm{kWh} /$ year.

According to the National Statistical Institute [21], the average electricity consumption for street lighting per 1 inhabitant of the population is $29.12 \mathrm{kWh} /$ year. Therefore the municipality of Pravets has great potential for electricity saving and appropriate ECMs should be offered.

\section{Baseline of electricity consumption}

It was established that in 2016 in the town of Pravets the street lighting system worked on an average of 11.37 hours per day or 4,150 hours/year, i.e. $100 \%$ of the theoretically determined $4,150 \mathrm{~h}$ and similarly in the villages of the municipality the street lighting system worked on an average of 11.25 hours per day or 4,106 hours/year, ie. $100 \%$ of the theoretically determined $4100 \mathrm{~h}$. 
The theoretical period during which artificial lighting of external public spaces is necessary was determined on the basis of the Astronomical calendar of Bulgaria [22].

The baseline is the sum of the required installed capacity of all luminaires with an annual load of $4,150 \mathrm{~h}$ for the town of Pravets and 4,100 $\mathrm{h}$ for the rest villages of the municipality at $100 \%$ full-night and year-round illumination of street lighting. The implementation of these criteria leads to the satisfaction of normal requirements for brightness of different categories streets. It was established that the light-emitting indicators of the available luminaires constituting the municipal street lighting system do not meet the minimum requirements of the standard for any category of street. To achieve the standard brightness (luminance) criteria as well as the requirement for uniformity of illumination, it is necessary to install additional luminaires with the corresponding power. Table 4 shows the installed capacity of street lighting at baseline, both for the town of Pravets and for the rest villages in the municipality.

Table 4. Baseline electricity consumption in the municipality of Pravets

\begin{tabular}{|c|c|c|c|c|c|c|}
\hline \multirow{2}{*}{ Settlement } & \multicolumn{2}{|c|}{ Number of lighting } & \multicolumn{2}{c|}{ Installed power, $\mathbf{k}$} & \multicolumn{2}{c|}{ Base electricity consumption } \\
\cline { 2 - 7 } & $\begin{array}{c}\text { Current } \\
\text { value }\end{array}$ & $\begin{array}{c}\text { Base } \\
\text { value }\end{array}$ & $\begin{array}{c}\text { Current } \\
\text { value }\end{array}$ & $\begin{array}{c}\text { Base } \\
\text { value }\end{array}$ & kWh/y & $\begin{array}{c}\mathrm{kWh} / \mathrm{y} \\
\text { per 1 inhabitant }\end{array}$ \\
\hline Town of Pravets & 1,672 & 1,722 & 128.54 & 132.89 & 551,494 & 125.14 \\
\hline Other villages & 968 & 1,429 & 51.413 & 86.819 & 355,958 & 104.87 \\
\hline Total & $\mathbf{2 , 6 4 0}$ & $\mathbf{3 , 1 5 1}$ & $\mathbf{1 7 9 . 9 5 3}$ & $\mathbf{2 1 9 . 7 0 9}$ & $\mathbf{9 0 7 , 4 5 2}$ & - \\
\hline
\end{tabular}

\section{Classification of streets and selection of normative indicators}

Street Lighting Standards [11, 19] place a major focus on efficient use of electricity and take into account the functional purpose of streets and roads and introduce light technical classification. The first step in the identification of the ECMs is the correct determination of the light class of the different categories streets in the settlement under [11, 19]. The road network in the town of Pravets consists of urban highways II class, class III arterial streets, a secondary street network including collection streets IV class and serving streets V class. The standard light-emitting indicators for the different categories of streets and pedestrian spaces in the town of Pravets are presented in Table 5.

Table 5. Lighting requirements for different categories streets and pedestrian spaces [15]

\begin{tabular}{|c|c|c|c|c|c|}
\hline \multirow{3}{*}{$\begin{array}{l}\text { Light } \\
\text { class }\end{array}$} & \multicolumn{5}{|c|}{ Lighting requirements for different categories streets } \\
\hline & Lcp. & $\begin{array}{c}\text { General } \\
\text { unevenness }\end{array}$ & $\begin{array}{c}\text { Longitudinal } \\
\text { unevenness }\end{array}$ & Dazzle & $\begin{array}{c}\text { Light } \\
\text { environments }\end{array}$ \\
\hline & $\mathbf{c d} / \mathbf{m} 2$ & $\mathbf{V}_{0}$ & $\mathbf{V}_{\mathrm{L}}$ & TI (\%) & SR \\
\hline M3 & $\geq 1$ & $\geq 0,4$ & $\geq 0,6$ & $\leq 15$ & $\geq 0,3$ \\
\hline M4 & $\geq 0,75$ & $\geq 0,4$ & $\geq 0,6$ & $\leq 15$ & $\geq 0,3$ \\
\hline M5 & $\geq 0,5$ & $\geq 0,35$ & $\geq 0,4$ & $\leq 15$ & $\geq 0,3$ \\
\hline M6 & $\geq 0,3$ & $\geq 0,35$ & $\geq 0,4$ & $\leq 15$ & $\geq 0,3$ \\
\hline & \multicolumn{5}{|c|}{ Lighting requirements for pedestrian spaces } \\
\hline \multicolumn{2}{|c|}{ Light class } & \multicolumn{2}{|c|}{$\mathbf{E}_{\mathrm{cp} .}(\mathbf{l} \mathbf{x})$} & \multicolumn{2}{|c|}{$\mathbf{E}_{\min }(\mathbf{l} \mathbf{x})$} \\
\hline & & \multicolumn{2}{|c|}{$\geq 5$} & \multicolumn{2}{|c|}{$\geq 1$} \\
\hline
\end{tabular}

\section{Suggested energy conservation measures (ECMs)}

The options for saving electricity ware identified on the basis of which a package of energy saving measures (ECMs) was developed as follows: 
ECM 1: Replacement of all existing street luminaries (due to their low efficiency and strong amortization) with new LED luminaries - latest generation;

ECM 2: Installation of new LED luminaries in areas where there is no mounted lighting;

ECM 3: Installation of an appropriate control system of street lighting.

The development of LED technology is a prerequisite for high efficiency performance compared to conventional street lighting. For this reason, they are the most energy-efficient street lighting luminaire for the moment. The following types of LED street luminaries are selected for proposed ECMs in Pravets municipality: LED 55W; LED 40W; LED 27W; LED 14W; LED 6W and LED PARK $8 \mathrm{~W}$. The main results from the light technical calculations for different categories of streets in the municipality are presented in Table 6.

Table 6. Results from the light technical calculations for different categories of streets

\begin{tabular}{|c|c|c|c|c|c|}
\hline Indicator & $\begin{array}{c}\text { Operating } \\
\text { luminance }\left(\mathrm{cd} / \mathrm{m}^{2}\right)\end{array}$ & $\begin{array}{c}\text { General } \\
\text { unevenness }\end{array}$ & $\begin{array}{c}\text { Longitudinal } \\
\text { unevenness }\end{array}$ & Dazzle & SR \\
\hline \multicolumn{6}{|c|}{ Urban highways - LED 55W } \\
\hline Normative value & 1,0 & 0,40 & 0,60 & 15 & 0,30 \\
\hline Realized value & 1,03 & 0,42 & 0,64 & 12 & 0,32 \\
\hline \multicolumn{6}{|c|}{ Arterial streets LED $40 \mathrm{~W}$} \\
\hline Normative value & 0,75 & 0,40 & 0,60 & 15 & 0,30 \\
\hline Realized value & 0,78 & 0,44 & 0,68 & 12 & 0,33 \\
\hline \multicolumn{6}{|c|}{ Collection streets $-27 \mathrm{~W}$} \\
\hline Normative value & 0,50 & 0,35 & 0,40 & 15 & 0,30 \\
\hline Realized value & 0,52 & 0,38 & 0,42 & 13 & 0,33 \\
\hline \multicolumn{6}{|c|}{ Serving streets $-14 \mathrm{~W}$} \\
\hline Normative value & 0,30 & 0,35 & 0,40 & 15 & 0,30 \\
\hline Realized value & 0,32 & 0,38 & 0,42 & 13 & 0,33 \\
\hline \multicolumn{6}{|c|}{ Decorative lighting $-6 \mathrm{~W}$} \\
\hline Normative value & 0,20 & 0,35 & 0,40 & 15 & 0,30 \\
\hline Realized value & 0,22 & 0,38 & 0,42 & 13 & 0,33 \\
\hline \multicolumn{6}{|c|}{ Park lighting $-8 \mathrm{~W}$} \\
\hline Normative value & $5 \operatorname{lux}$ & \multicolumn{4}{|c|}{ minimum illumination -1 lux } \\
\hline Realized value & 5,05 lux & \multicolumn{4}{|c|}{ maximum illumination $-1,1$ lux } \\
\hline
\end{tabular}

Table 7. Distribution of LED street and park lighting by number and power

\begin{tabular}{|c|c|c|c|c|}
\hline № & Street type & Number of lighting & Power, W & Total power, $\mathbf{k W}$ \\
\hline \multicolumn{5}{|c|}{ Town of Pravets } \\
\hline 1 & Urban highways & $76+36=112$ & LED 55+ LED 27 & $4.18+0.972$ \\
\hline 2 & Arterial streets & 185 & LED 40 & 7.4 \\
\hline 3 & Collection streets & 94 & LED 27 & 2.538 \\
\hline 4 & Serving streets & 697 & LED 14 & 9.758 \\
\hline 5 & Decorative lighting & 426 & LED 6 & 2.556 \\
\hline 6 & Park lighting & 158 & LED Park $8 \mathrm{~W}$ & 1.264 \\
\hline \multicolumn{7}{|c|}{ Total } & $\mathbf{1 6 7 2}$ & - & Pi $=\mathbf{2 8 . 6 6 8}$ \\
\hline \multicolumn{7}{|c|}{ Villages from the municipality } \\
\hline 1 & Arterial streets & $58+471=529$ & LED 40+ LED 27 & $2.32+12.717$ \\
\hline 2 & Collection streets & 551 & LED 14 & 7.714 \\
\hline 3 & Serving streets & 377 & LED 8 & 3.016 \\
\hline
\end{tabular}




\begin{tabular}{|c|c|c|c|c|}
\hline 4 & Park lighting & $23+21=44$ & LED Park $8+14$ & $0.184+0.294$ \\
\hline \multicolumn{2}{|c|}{ Total } & $\mathbf{1 5 0 1}$ & - & $\mathbf{P i}=\mathbf{2 6 . 2 4 5}$ \\
\hline
\end{tabular}

After the light technical calculations, the type and number of street lights for the municipality were determined and their distribution by category of streets is presented in Table 7. The total installed power of the lighting after the implementation of ECMs would be $54.913 \mathrm{~kW}$ and the annual electricity consumption would be $226,576.5 \mathrm{kWh}$.

A new automated street lighting control system will be built in Pravets. The distribution boards will be replaced by new ones located outside the electric substations. Some boards in the town of Pravets will be equipped with new meters, standard interface controllers and GPRS transmitters. The control system will provide information to a control station in real time. In case of incidents an alarm signal will be sent to the control station. These features will allow real-time monitoring of current electricity consumption and in case of incident, theft or other critical circumstances, the operator will be able to respond immediately. For other villages in the municipality, the automated street lighting control system will not have a significant effect on energy savings. This is explained by the low electricity consumption of street lighting. Due to the above facts, such type of automatic control system will not be implemented in other villages in the municipality.

\section{Economic evaluations of energy conservation measures}

The financial parameters of the project are calculated with specialized software Economy Software 6.26 - ENSI 2002-2004. The calculations were made at an average interest rate of $8 \%$ and inflation for $2016-0.1 \%$ according to [21].

The investment for implementation of the proposed package ECMs (auditing, designing and building of the new lighting system) is $414,840 €$.

The average price of electricity without VAT for 2016 for two-rate metering $(67 \%$ night rate and $33 \%$ daily rate) is $0.084 € / \mathrm{kWh}$.

The implementation of energy saving projects will reduce the amount of $\mathrm{CO}_{2}$, emitted into the atmosphere. The savings from $\mathrm{CO}_{2}$ were determined by the saved electricity and an emission factor of $819 \mathrm{~g} / \mathrm{kWh}$ according to [23]. The annual electricity and $\mathrm{CO}_{2}$ emissions savings after the implementation of new LED street lighting system compared to the baseline are presented in Table 8 . The annual savings for street lighting are expected to be $57,441 € / y$.

Table 8. Annual electricity and $\mathrm{CO}_{2}$ savings after the implementation of ECMs

\begin{tabular}{|c|l|c|c|c|c|c|}
\hline \multirow{2}{*}{ № } & \multicolumn{1}{|c|}{ State } & \multirow{2}{*}{$\begin{array}{c}\text { Number of } \\
\text { lighting }\end{array}$} & Power & $\begin{array}{c}\text { Annual electricity } \\
\text { consumption }\end{array}$ & $\begin{array}{c}\mathbf{C O}_{\mathbf{2}} \\
\text { emissions }\end{array}$ & $\begin{array}{c}\text { Specific electricity } \\
\text { consumption }\end{array}$ \\
\cline { 4 - 7 } & & $\mathbf{k W}$ & $\mathbf{k W h} / \mathbf{y}$ & $\mathbf{t C O}_{\mathbf{2}} / \mathbf{y}$ & $\mathbf{k W h / \mathbf { y } \text { per 1 inhabitant }}$ \\
\hline 1 & Baseline & 3151 & 219.709 & 907,451 & 743.20 & 116,33 \\
\hline 2 & After ECMs & 3173 & 54.913 & 226,577 & 185.56 & 29,04 \\
\hline 3 & Savings & - & 164.796 & 680,875 & 557.64 & 87,29 \\
\hline
\end{tabular}

After implementation of the ECMs, an effective street lighting maintenance plan will be developed, which will minimize the total annual O\&M costs. The O\&M costs for the street lighting in the municipality of Pravets according the baseline are 15,274 €/y. After the introduction of energy-efficient LED street lighting with a 5 year warranty, O\&M costs are expected to be $4,021 € / y$. Therefore the annual savings from O\&M costs will be $11,253 € / y$ 
and the total annual savings will be $68,694 € / \mathrm{y}$. The payback period according to the achieved savings compared to baseline is 6.04 years. Net present value is $265,053 €$ and internal rate of return is $16 \%$. After implementation of the ECMs, the specific energy consumption will decrease by $75.03 \%$ compared to the baseline.

\section{Conclusion}

The energy audit of the street lighting system in the Pravets municipality was carried out in compliance with the legislation in force in the EU and Bulgaria.

The proposed LED lights for street and park lighting are the latest generation and this ensures maximum reduction of electricity and $\mathrm{CO}_{2}$ emissions and high operational reliability (minimum warranty of 5 years). The main part of the selected street and park lighting are with power of $8 \mathrm{~W}, 14 \mathrm{~W}$ and $27 \mathrm{~W}$ and dimming during the night hours (from 23:00 to 5:00) is not provided for the following reasons:

- According to European and world practices, dimming for streets and pedestrian areas of categories (M6, M5 and S4) is not foreseen, as the value of brightness and illumination falls well below critical limit;

- The necessary initial investment to realize the nighttimes dimming function with $8 \mathrm{~W}$, $14 \mathrm{~W}$ and $27 \mathrm{~W}$ lighting is significant compared to the symbolic savings it would bring.

The overall effect of putting the new, energy-efficient LED street lighting into operation is as follows:

- decrease of the annual $\mathrm{CO}_{2}$ emissions, compared to the baseline by 557,636 tons;

- decrease of the annual electricity costs, compared to the baseline by $57,441 €$;

- annual specific electricity consumption for street lighting per 1 inhabitant is $29.04 \mathrm{kWh}$ and is lower than the national average value $-29.12 \mathrm{kWh}$;

- reduction of the annual O\&M costs of the street lighting by $11,253 €$;

- total reduction of annual electricity consumption and O\&M costs compared to baseline by $68,694 €$;

- the new LED street lighting meets the requirements of EN 13201;

- the required investment amounts to $414,840 €$ and the payback period according to the annual electricity savings is 6.04 years;

- after implementation of the ECMs, the specific energy consumption in relation to the baseline will decrease by $75.03 \%$.

\section{References}

1 N. Anisimova, The capability to reduce primary energy demand in EU housing, Energy and Buildings, 43 (10), pp. 2747-2751 (2011)

2 C.A. Balaras, A.G. Gaglia, E. Georgopoulou, S. Mirasgedis, Y. Sarafidis, D.P. Lalas, European residential buildings and empirical assessment of the Hellenic building stock, energy consumption, emissions and potential energy savings, Buildings and Environment, 42 (3), pp. 1298-1314 (2007)

3 S. Lechtenbohmer, A. Schuring, The potential for large-scale savings from insulating residential buildings in the EU, Energy Efficiency, 4(2), pp. 257-270 (2011)

4 G. Valtchev, Energy Efficiency and Protection of the Environment. Scientific Conference, University in Town of Chanak Kale, Turkey, (2010)

5 G. Lazaroiu, V. Berbece, L. Mihaescu, I. Pisa, G.-P. Negreanu, Biogas Production from Animal Protein Waste, an Environmental Protection Technology Coupled With Energy Production, Scientific Works of University of Food Technologies, Volume 64, Issue 1, (2017)

6 C.K. Gana, A.F. Sapara, Y.C. Muna, K.E. Chongb, Techno-economic Analyses of LED Lighting: A Case Study in UTeM'sFaculty Building, Procedia Eng. 53, pp. 208-216 (2013) 
7 F. Frantozzi, F. Leccese, G. Salvadory, M. Rocca, M. Garofalo, LED Lighting for Indoor Sports Facilities: Can its Use Be Considered as Sustainable Solution from a Techno-economic Standpoint? Sustainability, 8, 618-631 (2016)

8 G. Ciampi, A. Rosato, M. Scorpio, S. Sibilio, Retrofitting Solutions for Energy Saving in Historical BuildingLighting System, Energy Procedia 78, pp. 2669-2674 (2015)

9 I. Ramljak, I. Ramljak, M. Sesar, Reconstruction of the Street Lighting Sustem as a Tool for Electrical Energy Savings, International Journal of Electrical and Computer Engineering Systems, Volume 7, Number 2, pp. 71-81 (2016)

10 R. Velaga, A. Kumar, Techno-economic Evaluation of the Feasibility of a smart street sustem\& A Case Study of Rural India, Procedia Social and Behavioral Sciences, 62, pp. 1220-1224 (2012)

11 Bulgarian Standard BDS EN 13201Road lighting (2016) [in Bulgarian]

12 Ordinance № E-RD-04-05 for Determining the Indicators of Energy Consumption, Energy Characteristics of Enterprises, Industrial Systems and External Artificial Lighting Systems, and for Determining Terms and Conditions for Performing Energy Efficiency Activities and Preparing the Energy Savings Assessment of the Minister of Energy and the Minister of Economy (2016) [in Bulgarian]

13 Low of Energetics (2003) [in Bulgarian] available from: https://www.me.government.bg/en/library/zakon-za-energetikata-256-c25-m0-1.html

14 Ordinance № Е-РД-04-1 for circumstances subject to entry in the registers under the Energy Efficiency Act, its registration receiving information from these registers, the terms and conditions for obtaining a qualification from energy efficiency consultants of the Minister of Energy and the Minister of Regional Development and Public Works (2018) [in Bulgarian]

15 Bulgarian Standard BDS EN 60598-1 / 2 - Lighting (2015) [in Bulgarian]

16 Energy Efficiency Act (2015), Available from: https://www.seea.government.bg/documents/

17 Low of Spatial Planning (2001)[in Bulgarian]

18 Ordinance № 3 on the structure of electrical installations and power lines of the Minister of Energy (2004) [in Bulgarian]

19 CIE 115:2010 Lighting of Roads for Motor and Pedestrian Traffic (2010)

20 Bulgarian Standard BDS 5504-82 "Lighting of streets and pedestrian zones (1982) [in Bulgarian]

21 Statistical data (2016) [in Bulgarian] Available from: http://www.nsi.bg./bg/content/766

22 Astronomical Calendar (2016) [in Bulgarian] Available from: http://nao-rozhen.org/astrocalendar/2016/Astronomical_calendar_2016.pdf

23 Ordinance № Е-РД-04-2 on the energy consumption and energy performance indicators for buildings of the Minister of Energy and the Minister of Regional Development and Public Works (2016) [in Bulgarian] 